\title{
An Integrative, Multiparametric Approach for the Comprehensive Assessment of Microbial Quality and Pollution in Aquaculture Systems
}

\author{
Loredana Stabili $^{1,2} \cdot$ Marco Di Salvo $^{1} \cdot$ Pietro Alifano $^{1} \cdot$ Adelfia Talà $^{1}$ \\ Received: 15 December 2020 / Accepted: 8 March 2021 / Published online: 4 May 2021 \\ (C) The Author(s) 2021
}

\begin{abstract}
As the aquaculture sector significantly expanded worldwide in the past decades, the concept of sustainable aquaculture has developed with the challenge of not only maximizing benefits but also minimizing the negative impacts on the environment assuring, at the same time, food security. In this framework, monitoring and improving the microbiological water quality and animal health are a central topic. In the present study, we evaluated the seawater microbiological quality in a mariculture system located in a Mediterranean coastal area (Northern Ionian Sea, Italy). We furnished, for the first time, a microbial inventory based on conventional culture-based methods, integrated with the 16S rRNA gene metabarcoding approach for vibrios identification and diversity analyses, and further implemented with microbial metabolic profiling data obtained from the Biolog EcoPlate system. Microbiological pollution indicators, vibrios diversity, and microbial metabolism were determined in two different times of the year (July and December). All microbial parameters measured in July were markedly increased compared to those measured in December. The presence of potentially pathogenic vibrios is discussed concerning the risk of fish disease and human infections. Thus, the microbial inventory here proposed might represent a new multiparametric approach for the suitable surveillance of the microbial quality in a mariculture system. Consequently, it could be useful for ensuring the safety of both the reared species and the consumers in the light of sustainable, eco-friendly aquaculture management.
\end{abstract}

Keywords Mariculture system $\cdot$ Microbial pollution indicators $\cdot$ Vibrios diversity $\cdot$ Biolog system $\cdot 16$ S rRNAgenemetabarcoding analysis

\section{Introduction}

The human population is increasing by 83 million each year, as revealed in a FAO report, leading to a daunting challenge of feeding a growing global population, which is expected to reach 8.6 billion by 2030 [1]. This growing global population, indeed, needs a steady supply of high-quality protein. Therefore, to meet this demand for food, aquaculture production, i.e., the farming of aquatic organisms (e.g., fish, mollusks, and crustaceans) and seaweeds must be increased. The

Loredana Stabili

loredana.stabili@irsa.cnr.it

1 Department of Biological and Environmental Sciences and Technologies, University of Salento, Lecce, Italy

2 Water Research Institute of the National Research Council, (IRSA-CNR), Taranto, Italy need for seafood cannot be gained by capture fisheries alone, due to the overfishing of fish stocks.

Aquaculture offers incontestable advantages, such as the production of good quality and accessible food for the population, the creation of an enormous number of jobs, and the generation of a remarkable budget for the developing countries. Nevertheless, there is an ongoing concern about the environmental risks posed by this economic activity, including water pollution, eutrophication, habitat destruction, biotic depletion, ecological effects, and disease outbreaks that have been and can be caused $[2,3]$. In particular, in the marine environment, fish farming causes eutrophication processes since many metabolic byproducts, food residuals, fecal matter, and residues of prophylactic and therapeutic inputs are discharged without treatment.

The increased organic matter inputs in the proximity of the fish cages may produce a detrimental effect on seafloor integrity and benthic microbial organisms $[4,5]$, as well as deterioration of water quality and disease outbreaks $[6,7]$. Moreover, conspicuous discharge of pathogen agents as 
bacteria, viruses, and protozoans from human and animal waste, such as sewage outfalls, accidental spillage and discharge from boats, overload from septic systems during high rainfall events, agricultural practice, and input from native animal species, into the marine environment has become a major alarm for the aquaculture industry [8].

The increase of bacterial pathogen loads in the aquaculture environment leads to two major consequences. The first one is that pathogenic bacteria may produce infections of reared species and, consequently, aquaculture diseases [9]. The second consequence is that the seafood products, severely contaminated by pathogenic bacteria, can pose a severe risk to human health due to human consumption [9].

Most bacteria responsible for disease belong to the normal flora of the water and can cause infection only when the reared species are stressed due to several factors, including unsuitable diet, poor farming techniques, and poor environmental quality. In aquaculture, high mortality rates and skin lesions on fish are due to diseases of microbial origin with subsequent economic losses worldwide in the range of about US\$ 6 billion per year $[10,11]$. Bacteria, mainly belonging to the genus Vibrio, such as Vibrio ordalii, V. harveyi, V. vulnificus, V. parahaemolyticus, $V$. alginolyticus, and $V$. salmonicida, have been considered as the etiological agents involved in the most common fish and shellfish disease outbreaks, called vibriosis [12, 13]. Moreover, the accumulation of these microorganisms in the reared animal's flesh may become a serious threat also to human health.

In addition to vibrios, another important category of microorganisms involved in aquaculture systems management is represented by the microbial pollution indicators. In particular, fecal contamination of the coastal aquatic environments is a major concern. Concentrations of fecal indicator bacteria are commonly used to identify the microbial quality of fish, shellfish, and growing waters $[14,15]$. Therefore, based on these considerations, it is evident that microorganisms are of great importance to aquaculture, where they occur naturally or can be unintentionally introduced as contaminants. In the aquaculture environment, microorganisms are involved in nutrients recycling, organic matter degradation, and, occasionally, in infection and death of farmed fishes. Moreover, some microbes may play a role in protecting fish and larvae against disease.

Although the effects of fish farming on sediments and meiofauna have been evaluated in a lot of studies [2, 16, 17], knowledge of the influence of aquaculture practices on the microbial compartment is still scant [18-20], and there is a relatively little knowledge of the effects on the microbial metabolism $[21,22]$. As reported in recent studies, the microbial diversity and metabolisms are affected by the local environment and rapidly respond to environmental changes $[23,24]$. Therefore, the responses of microbial communities related to environmental changes can be employed as sensitive "sentinels". Based on this concept, we collectively examined for the first time, a set of microbiological parameters simultaneously measured in a mariculture fish farm located in the Mediterranean Sea, producing the European sea bass Dicentrarchus labrax (Linnaeus, 1758) and sea bream Sparus aurata (Linnaeus, 1758). In particular, the following microbial parameters were evaluated in two different times (July and December) of the year: total coliforms, fecal coliforms, fecal enterococci, culturable heterotrophic bacteria at $22{ }^{\circ} \mathrm{C}$, culturable heterotrophic bacteria at 37 ${ }^{\circ} \mathrm{C}$, and culturable vibrios.

Conventional culture-based methods were integrated with the 16S rRNA gene metabarcoding approach for vibrios identification and diversity analysis. Furthermore, in addition to microbial parameters, we evaluated the potential metabolic profiles resulting from the Biolog EcoPlate system, a rapid tool to screen environmental microorganisms by their metabolic fingerprint [25]. Therefore, the paper aims to furnish a microbial inventory and an integrative, multiparametric approach for aquaculture systems management, in order to assess water quality and control the development of microbial infection.

\section{Material and Methods}

\section{Sample Collection}

In July 2018 and December 2018, seawater samples were collected from a mariculture fish farm (Maricoltura Margrande) of $0.06 \mathrm{~km}^{2}$, located at Mar Grande of Taranto (Northern Ionian Sea), $600 \mathrm{~m}$ away from the coast (Fig. 1). The plant is dedicated to the rearing of sea bass (Dicentrarchus labrax) and sea bream (Sparus aurata), for a total annual production of about 100 tons. The fish farm consisted of 16 cages with a diameter of about 20 $\mathrm{m}$ (circumference of about $60 \mathrm{~m}$ ) fixed to the bottom through appropriate buoys at a depth ranging from 7 to $8 \mathrm{~m}$ (Fig. 1). For each month (July and December), water samples were collected from four replicates sampling points (SP1, SP2, SP3, and SP4) at the periphery of the four fish cages located at the four corners of the farming plant, using 5-L Niskin bottles at a depth of $0.5 \mathrm{~m}$. Niskin bottles were previously washed with $0.1 \mathrm{~N} \mathrm{HCl}$ and then rinsed with sterilized and filtered (through Millipore $0.2-\mu \mathrm{m}$ filters) water, as previously reported [26]. Samples were placed on ice and transferred to the laboratory within $4 \mathrm{~h}$ for further processing.

\section{Microbiological Analyses}

\section{Enumeration of Culturable Bacteria at $22^{\circ} \mathrm{C}$ and $37^{\circ} \mathrm{C}$}

Traditional plate counting on agar is a classic culture-dependent technique to evaluate bacterial numbers [27]. In the drinking water sector, plate counting on agar is the only method incorporated in the legislation [28]. Within aquaculture, this is not a routine measurement. Despite the scant available data, this approach has been applied in some studies for detecting and/or 


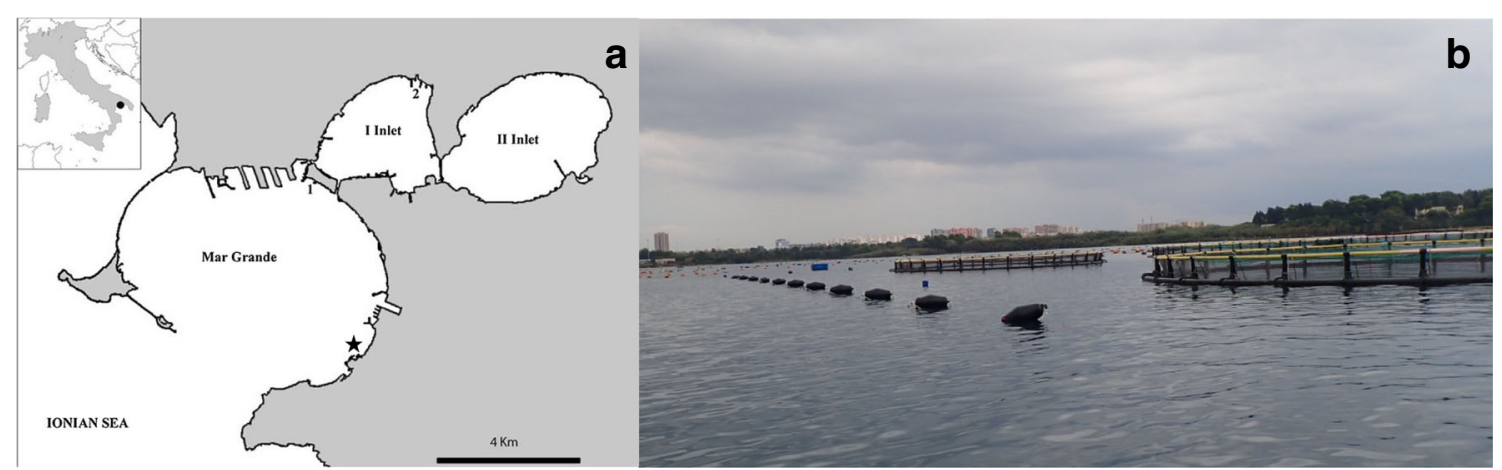

Fig. 1 Sampling station in the Mar Grande of Taranto (Northern Ionian Sea, Italy). a The geographical location of Maricoltura Margrande fish farm (black star) in the Mar Grande, Italy (full dot in the small box). b Mariculture fish farm photograph showing the fish cages with a diameter of about $20 \mathrm{~m}$

quantifying bacteria in aquaculture water [29, 30]. Here, in order to evaluate the concentration of culturable heterotrophic marine bacteria at $22^{\circ} \mathrm{C}, 1 \mathrm{~mL}$ of each seawater sample and appropriate decimal dilutions $\left(10^{-1}, 10^{-2}, 10^{-3}, 10^{-4}, 10^{-5}\right)$ were plated in triplicate onto Marine Agar 2216 (MA) [31]. After incubation of the plates seeded on MA in the dark at $22{ }^{\circ} \mathrm{C}$ for 7 days, the heterotrophic culturable bacteria were counted, according to the colony-forming units (CFU) method [32]. For total culturable bacteria at $37{ }^{\circ} \mathrm{C}$ counting, $1 \mathrm{~mL}$ of each seawater sample and appropriate decimal dilutions $\left(10^{-1}, 10^{-2}, 10^{-3}, 10^{-4}, 10^{-5}\right)$ were plated in triplicate onto Plate Count Agar (PCA) [31] and incubated at $37^{\circ} \mathrm{C}$ for $24-48 \mathrm{~h}$.

\section{Enumeration of Pollution Indicator Bacteria}

To assess the microbial water quality in an easy and reproducible way, standard methods (e.g. ISO - the International Organization for Standardization) were followed. In particular, total coliforms and fecal coliforms, as well as fecal enterococci, were determined by the Most Probable Number (MPN) method, using the standard five-tube method of ten-fold dilutions for seawater samples [33]. Coliform bacteria concentration was evaluated by using the miniaturized MPN, in accordance with ISO 9308-3:1998 [34]. Fecal enterococci were measured by using the miniaturized MPN method (incubation at $44{ }^{\circ} \mathrm{C}$ for $24-48 \mathrm{~h}$ ) [35].

\section{Enumeration and Isolation of Vibrio Species}

Culturable vibrios were enumerated by filtering 1,5 , and 10 $\mathrm{mL}$ of each seawater sample on $0.45-\mu \mathrm{m}$ pore size filters (Millipore). Aseptically, filters were placed onto thiosulphate-citrate-bile-salt-agar (TCBS) plus $2 \% \mathrm{NaCl}$, as already reported by [36]. Incubation was performed at 20 $-25^{\circ} \mathrm{C}$ and $35^{\circ} \mathrm{C}$ for 2 days. The incubation temperature of $35^{\circ} \mathrm{C}$ was selected to estimate the fraction of vibrios potentially pathogenic to humans. The incubation temperature of $20-25{ }^{\circ} \mathrm{C}$ was chosen since some Vibrio spp., such as Vibrio anguillarum, do not grow well at higher temperatures [37].
After incubation, the colonies of presumptive vibrios (yellow or green), grown on TCBS agar, were counted according to the colony-forming unit (CFU) method. Mean values from three replicates were calculated and expressed as $\mathrm{CFU} / \mathrm{mL}$.

\section{DNA Extraction and Metabarcoding-Based Taxonomic Identification of Cultured Vibrios}

All presumptive vibrios colonies grown on TCSB agar, for each replicate sample obtained from the different sites and sampling times, were recovered from the plates and processed for total genomic DNA extraction, according to standard procedures [38]. Extracted DNA was sent to Genomix4life S.R.L. (Baronissi, Salerno, Italy) for 16S rRNA gene metabarcoding and bioinformatics analysis aimed to bacterial identification. Final yield and control quality of extracted DNA were determined using a NanoDrop ND-1000 spectrophotometer (Thermo Scientific, Waltham, MA) and Qubit Fluorometer 1.0 (Invitrogen Co., Carlsbad, CA).

PCR amplifications and 16S rRNA gene metabarcoding sequencing were performed as previously described [39]. Taxonomic assignment of 16S rRNA-targeted amplicon reads was performed using ClassifyReads, a high-performance naïve Bayesian classifier of the Ribosomal Database Project (RDP) [40, 41]. ClassifyReads uses a 32-base word-matching strategy to determine the percentage of shared words between a query and the last available version of the Greengenes taxonomy database (greengenes.secondgenome.com/downloads). In ClassifyReads, the classification confidence is statistically assigned based on the overall accuracy of the classification algorithm at different taxonomic levels (100\% for kingdom, $100 \%$ for phylum, $100 \%$ for class, $99.98 \%$ for order, $99.97 \%$ for family, $99.65 \%$ for genus, $98.24 \%$ for species). Reads that did not match a reference sequence were categorized as "Unclassified" [42].

\section{Biolog EcoPlate Inoculation and Incubation}

In the present study, the Biolog EcoPlate system (BIOLOG Inc., Hayward, Calif.) was utilized. It represents a rapid tool to 
monitor environmental bacteria, evaluating their metabolic fingerprint [25] and has been already profitably employed in several marine environmental studies [43-45]. In this standardized method, the bacterial oxidation of 31 ecologically main carbon substrates, with a redox-sensitive tetrazolium indicator of microbial respiration, is determined [46]. In particular, the metabolized substrates include L-arginine, L-asparagine, L-phenylalanine, L-serine, L-threonine, glycyl-Lglutamic acid, phenylethyl-amine, and putrescine among amino acids; $\beta$-methyl-D-glucoside, D-xylose, i-erythritol, D-mannitol, N-acetyl-D-glucosamine, D-cellobiose, glucose-1-phosphate, $\alpha$-D-lactose, and D,L- $\alpha$-glycerol phosphate among carbohydrates; pyruvic acid methyl ester, D-galacturonic acid, 2hydroxy benzoic acid, 4-hydroxy benzoic acid, Dglucosaminic acid, itaconic acid, $\alpha$-ketobutyric acid, and Dmalic acid among carboxylic acids; tween 40 , tween 80 , cyclodextrin, and glycogen among polymers.

Briefly, from each seawater sample, three replicates were assayed using the Biolog EcoPlates, as previously reported [44]. After the inoculation of each well with $150 \mu \mathrm{L}$ of the sample, the plates were incubated at $22^{\circ} \mathrm{C}$ for 1 week $(168 \mathrm{~h})$. The optical density (OD) values were measured at a wavelength of $590 \mathrm{~nm}$ with a plate reader (Microplate Reader model 3550; Bio-Rad, Richmond, Calif.). The metabolic activity of the overall microbial community cultivated in Biolog microplates was expressed as average well color development (AWCD) [47]. AWCD values were calculated as absorbance at $590 \mathrm{~nm}$ after subtracting control well values [48].

\section{Statistical Analyses}

All statistical analyses were performed using the PAST 4.03 software [49]. The nonparametric two-sample $t$ test with Monte Carlo permutation was conducted to evaluate the presence of statistically significant differences between bacterial counts in seawater samples, collected in December and July. Statistical significance was considered at the 0.05 level. A two-sample unpaired Student's $t$ test was conducted to compare the Shannon diversity index for Vibrio species in December and July samples. Multivariate Principal Component Analysis (PCA) was performed to evaluate the distribution of culturable bacteria abundance and EcoPlates metabolic parameters at the PAST 4.3 software.

\section{Results}

\section{Bacterial Enumeration}

\section{Enumeration of Culturable Bacteria at $22{ }^{\circ} \mathrm{C}$ and $37^{\circ} \mathrm{C}$}

In Figs. 2a and b, bacterial concentrations of culturable bacteria at $22{ }^{\circ} \mathrm{C}$ and $37{ }^{\circ} \mathrm{C}$, respectively, are reported as mean values of three replicate plate counts, at the four sampling points (SP1, SP2, SP3, SP4). The mean concentration of culturable bacteria at $22^{\circ} \mathrm{C}$ in the seawater samples collected in December was $4.8 \pm 0.4 \times 10^{3} \mathrm{CFU} / \mathrm{mL}$. The counting of these bacteria increased to $1.8 \pm 0.2 \times 10^{4} \mathrm{CFU} / \mathrm{mL}$ in July samples (Fig. 2a').

Figure $2 b^{\prime}$ reports the concentrations of total culturable bacteria at $37{ }^{\circ} \mathrm{C}$ in the two sampling times. As already observed for culturable bacteria at $22^{\circ} \mathrm{C}$, the highest counting of this bacterial group was observed in July, with a mean value of $6.9 \pm 0.7 \times 10^{3} \mathrm{CFU} / \mathrm{mL}$. Lower abundances were instead recorded in December, with a mean value of $1.0 \pm 0.1 \times \mathrm{CFU} / \mathrm{mL}$.

\section{Microbial Pollution Indicators}

Total coliforms and fecal coliforms showed the highest values in July when $280 \pm 26 \mathrm{MPN} / 100 \mathrm{~mL}$ were recorded for total coliforms (Fig. $2 \mathrm{f}$ and $\mathrm{f}^{\prime}$ ), and $130 \pm 14 \mathrm{MPN} / 100 \mathrm{~mL}$ for fecal coliforms (Fig. $2 \mathrm{~d}$ and $\mathrm{d}^{\prime}$ ). In December lower values were observed compared to those recorded in July. The counting of fecal enterococci ranged from $17 \pm 3$ to $49 \pm 6 \mathrm{MPN} / 100$ $\mathrm{mL}$ in July, with the mean value of $33 \pm 2.7 \mathrm{MPN} / 100 \mathrm{~mL}$. In December the mean counting of this microbiological parameter was about $1 \mathrm{MPN} / 100 \mathrm{~mL}$ (Fig. 2e and $\mathrm{e}^{\prime}$ ).

\section{Enumeration and Diversity of Vibrio Species}

In Fig. 2c, bacterial concentrations of culturable vibrios are reported as mean values of three replicate plate counts at the four sampling points (SP1, SP2, SP3, SP4). The lowest counting was observed in December, with a mean value of $3.8 \pm 0.9 \mathrm{CFU} / \mathrm{mL}$ (Fig. 2c'). By contrast, the vibrios abundance increased in July with a mean value of $1.3 \pm 0.1 \times 10^{2}$ $\mathrm{CFU} / \mathrm{mL}$.

In this study, we have used a $16 \mathrm{~S}$ rRNA gene metabarcoding approach to identify, at the species level, cultured vibrios grown on TCSB agar, and to simultaneously estimate their relative abundance. The metabarcoding analysis was performed on each pool of presumptive vibrios colonies recovered from TCSB agar, obtained from the different sites and sampling times. Sequencing of DNA extracted from July and December samples resulted in 749,421 total reads. These reads were quality filtered, and a total of 563,119 reads (ranging from 23,736 to 100,701 per sample) were selected as the most reliable reads for taxonomy assignment. On the whole, a total of 454,884 reads were classified to species level, ranging from 67.19 to $97.33 \%$ of total reads per sample. The metabarcoding raw data were refined by calculating the corresponding relative abundance, before using them as input variables for diversity and statistical analyses.

As expected, Vibrio was the dominant genus in all samples, other genera have also been detected, with a mean relative 

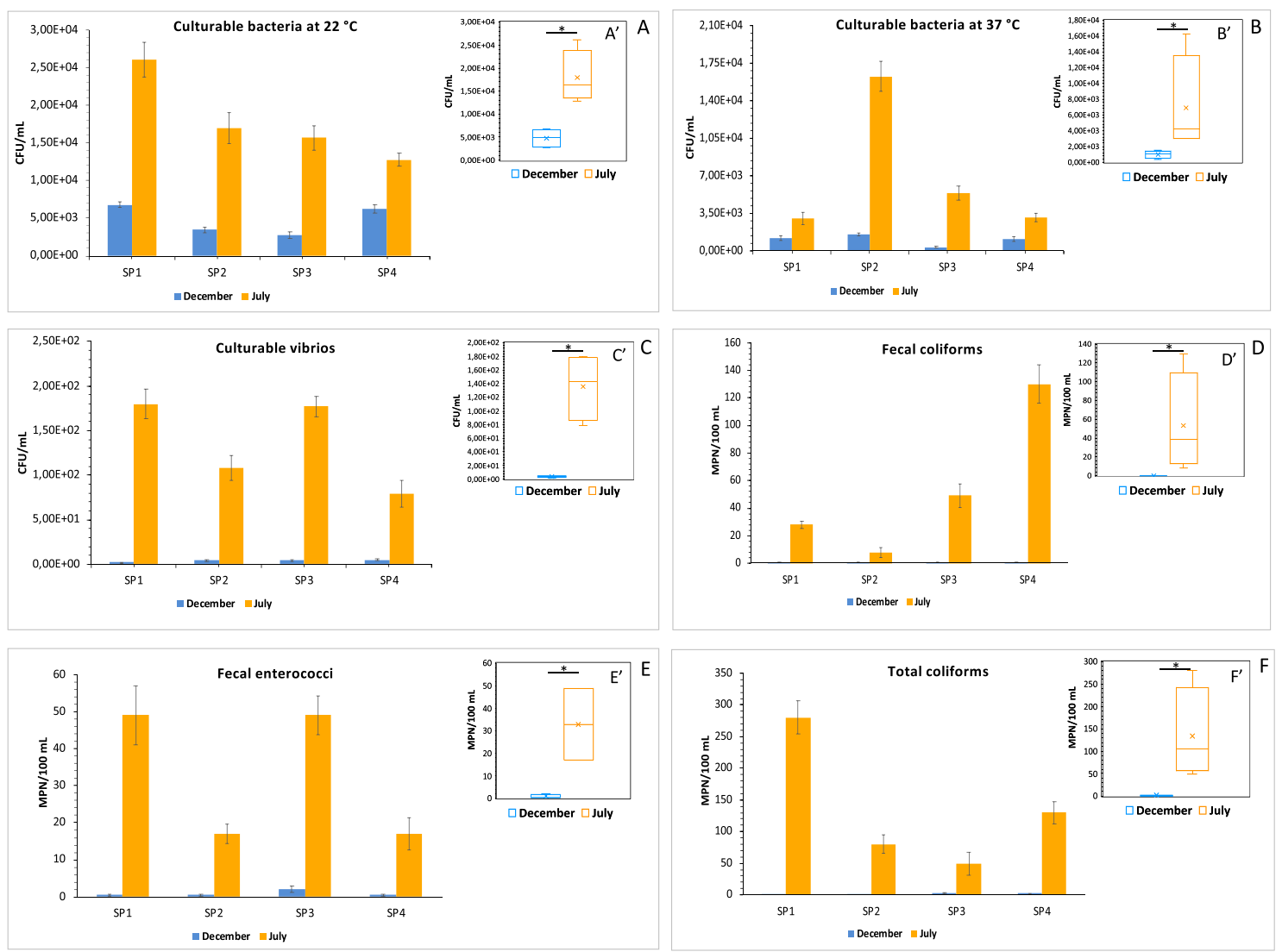

Fig. 2 Histograms showing concentrations of culturable bacteria in seawater samples collected in December and July. Bacterial counting is reported as mean values \pm S.D. of three replicate plate counts at the four sampling points (SP1, SP2, SP3, SP4). Bacterial counts are expressed as $\mathrm{CFU} / \mathrm{mL}$ for culturable bacteria at $22^{\circ} \mathrm{C}\left(\right.$ a), culturable bacteria at $37^{\circ} \mathrm{C}$

abundance of $2.10 \%$ and $1.02 \%$ for July and December pool samples, respectively. Unclassified reads mean values were significantly more abundant in July samples, indicating a higher contribution of presumptive novel bacterial species and, therefore, greater diversity in July than in December pool samples (28.39\% and $6.38 \%$ relative abundance, respectively) (Fig. 3a and b).

July and December sampling groups showed markedly different profiles of the most abundant cultured Vibrio species (within-sample relative abundance $>0.1 \%$, on average). Significant differences $(p<0.05)$ were detected in 14 cultured Vibrio species (V. rotiferianus, V. owensii, V. azureus, $V$. mediterranei, V. parahaemolyticus, V. diabolicus, $V$. hippocampi, V. natriegens, V. ponticus, V. variabilis, $V$. midae, V. shilonii, V. harveyi, V. vulnificus), that were predominant in July samples. The relative abundances of the remaining 12 most abundant cultured Vibrio species, classified as "common" (V. chagasii, V. fortis, V. comitans, $V$. aestuarianus, V. xuii, V. litoralis, V. coralliilyticus, $V$. neptunius, $V$. brasiliensis, $V$. neonatus, $V$. nereis, $V$. gallaecicus), were statistically comparable between the two sampling groups $(p>0.05)$ (Fig. 3b). Alpha diversity (b), and culturable vibrios (c) and as MPN/100 mL for fecal coliforms (d), fecal enterococci (e), and total coliforms (f). In $\mathbf{a}^{\prime}-\mathrm{f}^{\prime}$, concentration values reported in box-plots for December and July samples correspond to mean values of three replicate plate counts for each sampling point (SP1-4). The asterisk (*) indicates a $p$ value

(within-sample diversity) was also investigated using the Shannon diversity index, which accounts for both richness and evenness of the isolated Vibrio species. July pool samples had significantly increased Shannon Index $(p<0.05)$, compared to December pool samples (Fig. 3c).

\section{Bacterial Metabolic Profiles}

The heterotrophic bacterial communities in the seawater samples, collected during the two sampling times, showed different metabolic patterns based on the 31 carbon substrates included in the Biolog EcoPlate system. Measured in terms of growth over a range of carbon substrates, the highest metabolic activity was recorded for the microbial assemblages associated with seawater collected in July, showing the ability to degrade most of the investigated carbon sources, with the exceptions of two carboxylic acids ( $\gamma$-hydroxybutyric and Dgalactonic $\gamma$ lactone acids) (Fig. 4a-d). In December the unutilized substrates were putrescine, D-xylose, four carboxylic acids (D-galactonic $\gamma$ lactone, pyruvic acid methyl ester, 2hydroxy benzoic and 4-hydroxy benzoic acids) and $\alpha$ cyclodextrin. 


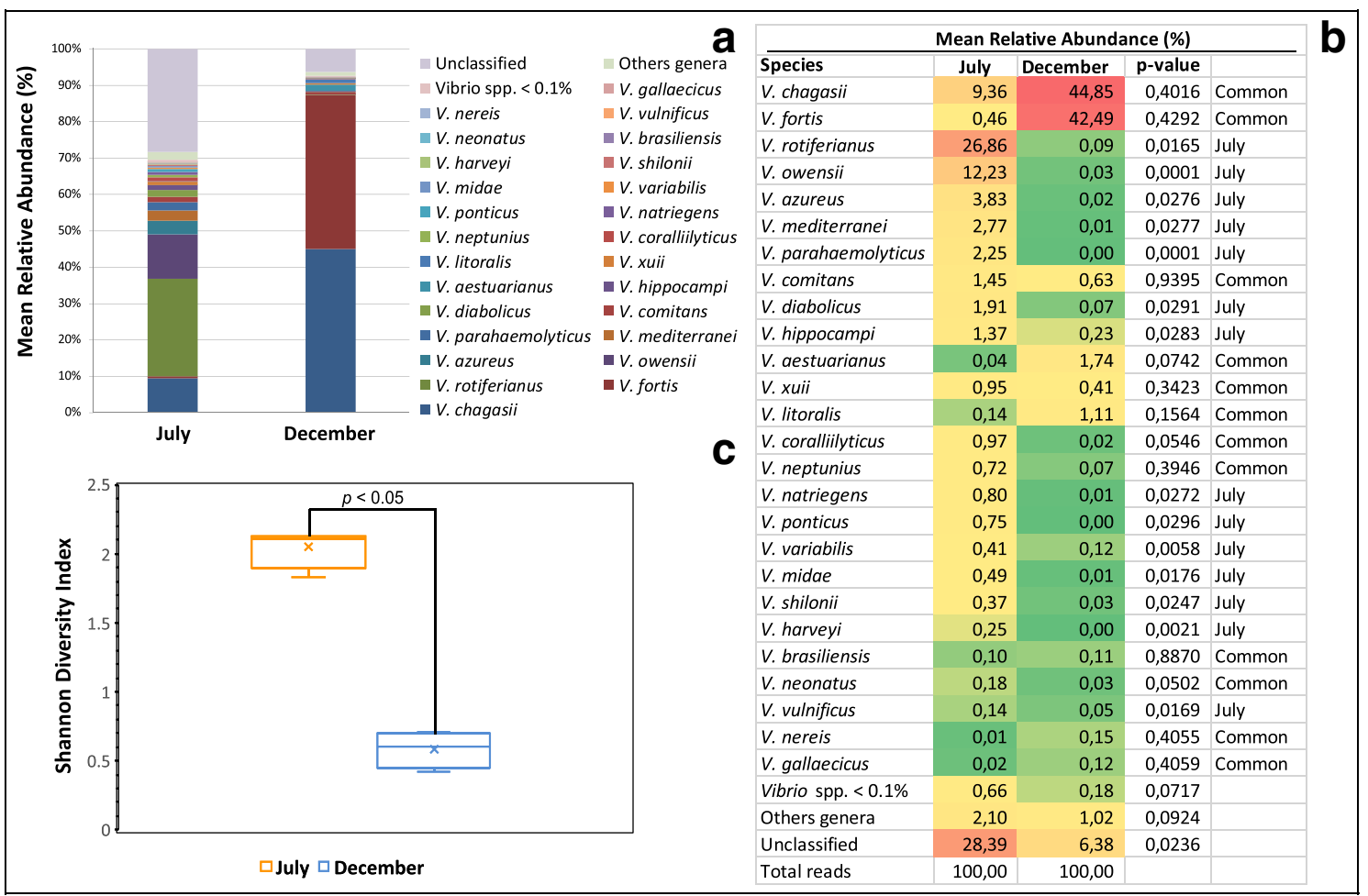

Fig. 3 Culturable vibrios diversity. a Mean relative percentage contribution for the 26 most abundant $(>0.1 \%$ within-sample mean relative abundance) vibrios species in July and December samples $(n=4)$. b Heat map showing the within-sample mean relative abundance of the 26 predominant Vibrio species $(>0.1 \%$ within-sample mean relative abundance) in July and December pool samples ( $n=4)$. In $\mathbf{a}$ and $\mathbf{b}$, the $<0.1 \%$

PCA multivariate analysis, in Fig. 5a-d, shows overall significant differences in metabolic patterns of the microbial community in the seawater samples collected in the two sampling times. In particular, a clear separation was evidenced in the amino acids, carbohydrates, carboxylic acids, and polymer utilization by the seawater microbial community of July and December (Fig. 5a-d).

\section{Microbial Inventory Overview}

Bacterial enumeration raw data, including culturable heterotrophic bacteria at $22{ }^{\circ} \mathrm{C}$, culturable bacteria at $37{ }^{\circ} \mathrm{C}$, culturable vibrios, total coliforms, fecal coliforms, fecal enterococci plate counts, and EcoPlate AWCD metabolic raw values were logarithmically (base 10) transformed to make variables comparable.

The multivariate PCA of the normalized cultural and metabolic parameters was performed to summarize and visualize the overall shape of the monitored variables in mariculture fish farm samples. PCA results are depicted in Fig. 6, where the principal components P1 and P2 explained $92.41 \%$ and $3.31 \%$ of the variance, respectively. Two main clusters representative of the December and July samples, located on the left and the right side of the $\mathrm{P} 1=0$ axis, respectively, were visualized in within-sample mean relative abundances, bacterial genera different from Vibrio, and unclassified bacterial species are denoted as "Vibrio spp. $<0.1 \%$ ", "Other genera", "Unclassified", respectively. c Box plot showing the Shannon diversity index for July $(n=4)$ versus December $(n=4)$. $p$ value displayed is the result of the $t$ test between the two groups ( $n=4$ per group)

the PCA plot. All the samples SP1-4 collected in July markedly differed from those collected in December for the higher bacterial counting and more versatile metabolic activity, highlighting the relevant impact of seasonality on the fish farm microbial community structure and function.

\section{Discussion}

Microbiological analyses, based on molecular and cultural methods, as well as on the potential metabolic assessment of the seawater microbiota, were performed in a fish farm located in a coastal Mediterranean area (Mar Grande, Northern Sea, Italy). Recently, the aquaculture industry, and particularly mariculture, is expanding worldwide and the challenges for this sector are numerous. These challenges include the development of a more sustainable production ensuring an environmentally sound industry, the availability to consumers of healthy, safe, and good quality products, as well as the promotion of high animal health and welfare standards. Little is known about fish farming impacts in the Mediterranean [20, 50], where rearing of marine species, particularly sea bream (Sparus aurata) and sea bass (Dicentrarchus labrax), has grown exponentially during the last years. For these reasons 
$\square$ December $\square$ July

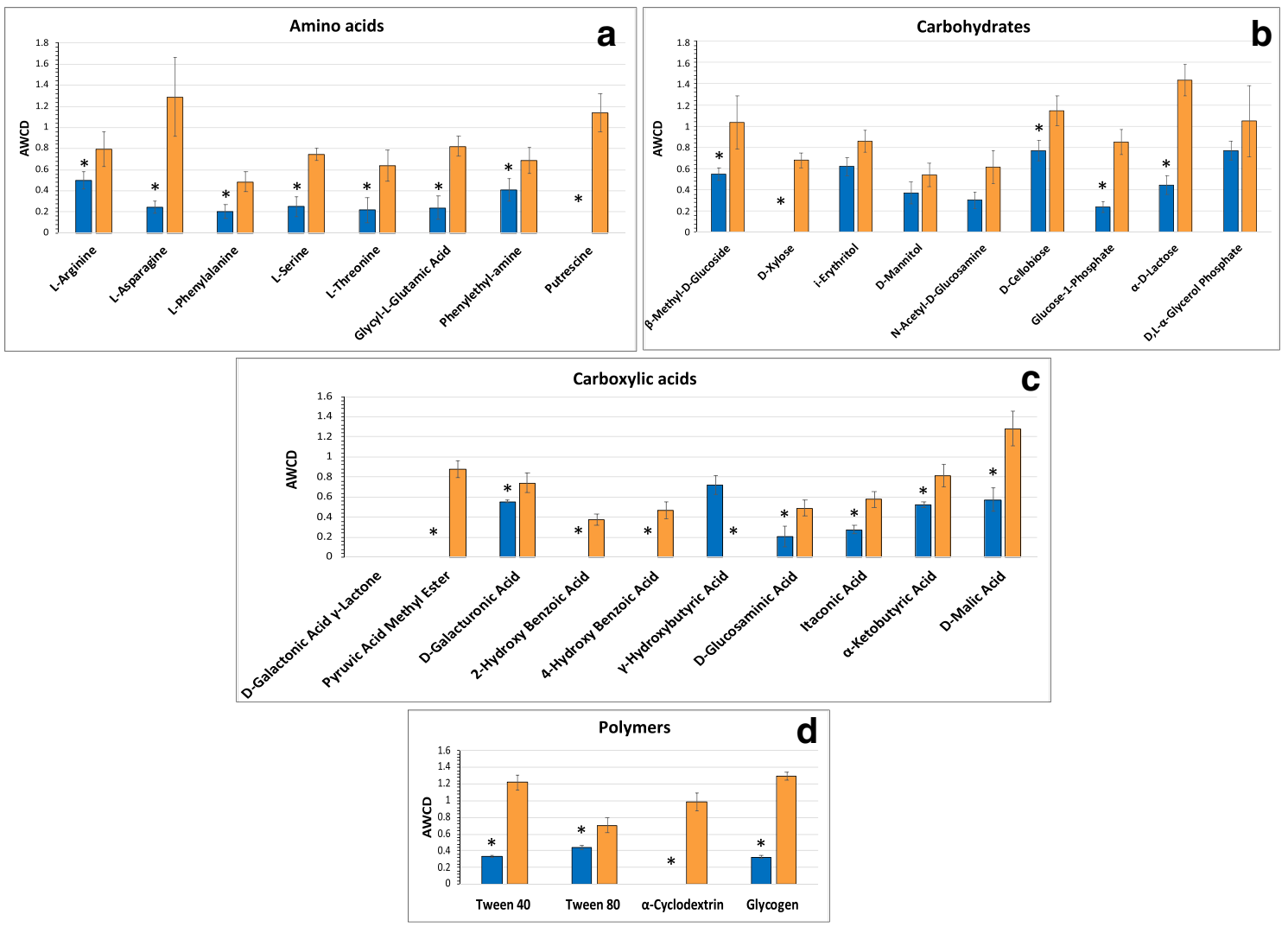

Fig. 4 Carbon sources utilization by the microbial communities in the seawater samples collected during the two sampling times. a Amino acids, $\mathbf{b}$ carbohydrates, $\mathbf{c}$ carboxylic acids, and $\mathbf{d}$ polymer utilization. Data were shown as mean values of AWCD in all sampling points
(SP1-4 December versus SP1-4 July) for each substrate, after $168 \mathrm{~h}$ of incubation. Error bars indicate the standard deviation of the mean $(n=4$ per group). Two-sample unpaired Student's $t$ test was used to calculate $p$ value $(*=p<0.05)$ microbial water quality control should be regarded as a central management factor/tool to be developed in this sector. In some cases, the most commonly measured parameters in aquaculture facilities are the number of total marine heterotrophs and the number of presumptive Vibrio, detected by plate counts [51,52]. Our study represents a starting point to monitor simultaneously several microbial parameters, also including the potential metabolic profile of the microbial community in a mariculture area of the Mediterranean Sea. From our results, some interesting issues can be inferred.

It is well known that heterotrophic bacteria play an important role in aquaculture, as it has been reported that they account for approximately $80 \%$ of the total bacteria, far superior to the number of autotrophic bacteria [53]. Moreover, the number of heterotrophic bacteria in the water is affected by many factors, among which temperature has a great influence [54], and the higher water temperatures in summer are more suitable for bacterial growth. According to these considerations, we recorded higher bacterial counting in July. Values of heterotrophic bacterial counting similar to those observed in the present study have been already recorded in other Mediterranean areas, where mariculture is practiced. In particular, Caruso et al. [55] investigated three Mediterranean sites, where off-shore mariculture was undertaken and found values of $6.5 \times 10^{2} \mathrm{CFU}$ $\mathrm{m} / \mathrm{L}$ (at Capo d'Orlando), $2.85 \times 10^{3} \mathrm{CFU} \mathrm{m} / \mathrm{L}$ (at Castellammare Gulf) and $1.95 \times 10^{3} \mathrm{CFU} \mathrm{m} / \mathrm{L}$ (at Porto Palo).

Heterotrophic microbial communities in water are also sensitive to changes in nutrient levels [56] deriving from dissolved and particulate substrates provided by aquaculture wastes. High stimulation in the mineralization process may be induced by organic inputs. These may be more or less pronounced depending on the labile or refractory nature of organic matter so that microbial counting and metabolic activities are expected to be enhanced in highly trophic enriched environments, such as intensive aquaculture farms [18]. According to these considerations, we evaluated the metabolic profiles of the microbial assemblages present in the seawater samples.

Our results showed that the aquaculture system was characterized by a microbial community particularly active in organic matter utilization. It is well known that dissolved organic matter (DOM) in the marine environment is a mixture of organic compounds and comprises both low and highmolecular weight solutes, including organic acids, 

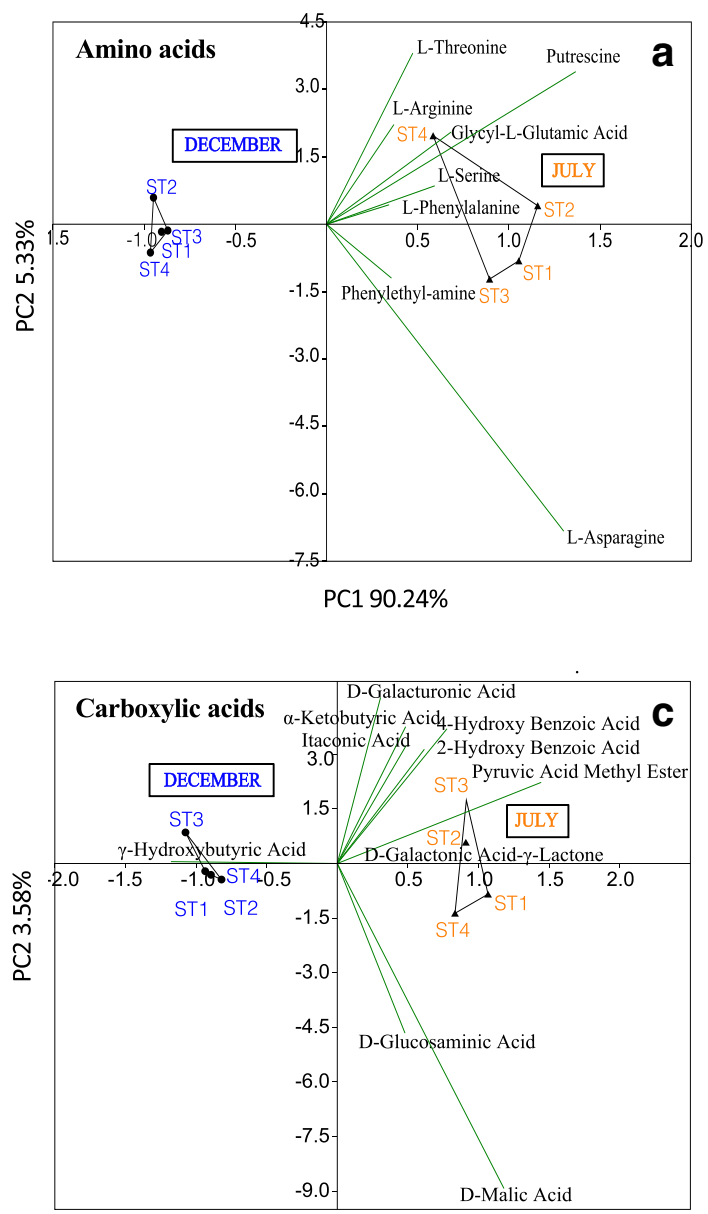

PC1 94.19\%

Fig. 5 Two-dimensional Principal Component Analysis (PCA) of microbial metabolic parameters for the December and July analyzed samples. a Amino acids, $\mathbf{b}$ carbohydrates, $\mathbf{c}$ carboxylic acids, and $\mathbf{d}$ polymer utilization. The input data is a matrix of multivariate data, with sampling groups ( $n=4$ per group) in rows and carbon sources in columns. December and

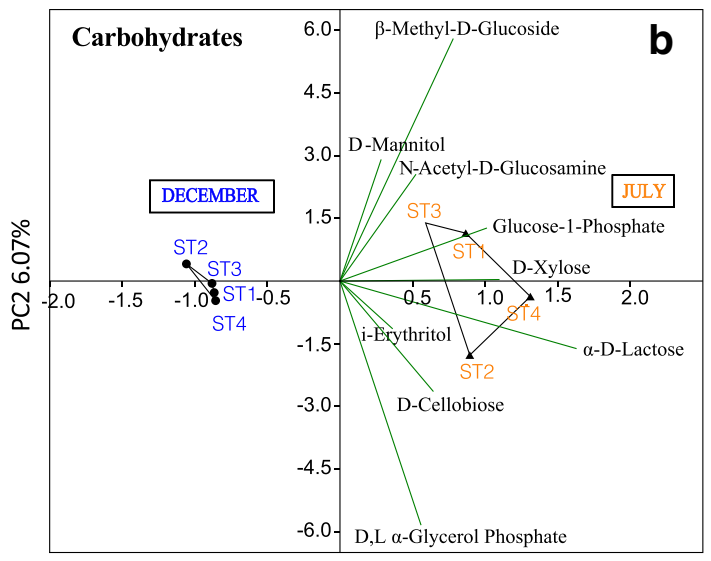

PC1 86.33\%

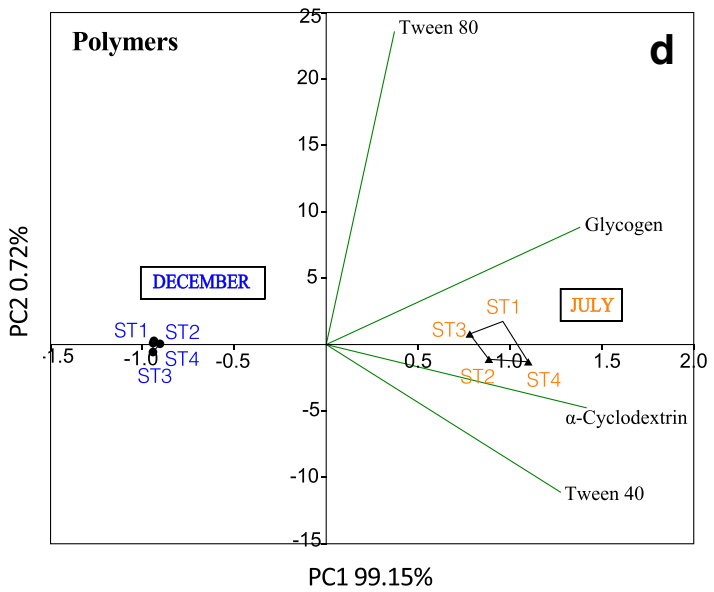

July samples are reported by black full dot and black full triangle, respectively. The percentages of the total variance explained by the first and second principal component ( $\mathrm{P} 1$ and $\mathrm{P} 2$, respectively) are also indicated in each plot
Fig. 6 Two-dimensional Principal Component Analysis (PCA) of normalized cultural (culturable bacteria at $22^{\circ} \mathrm{C}$, culturable bacteria at $37^{\circ} \mathrm{C}$, culturable vibrios, total coliforms, fecal coliforms, fecal enterococci) and metabolic (amino acids, carbohydrates, carboxylic acids, polymers) parameters, for the July and December pool samples $(n=4$ for each group). December and July samples are reported by dot and triangle, respectively. The percentages of the total variance explained by the first and second principal component ( $\mathrm{PC1}$ and $\mathrm{PC} 2$, respectively) are also indicated in the plot

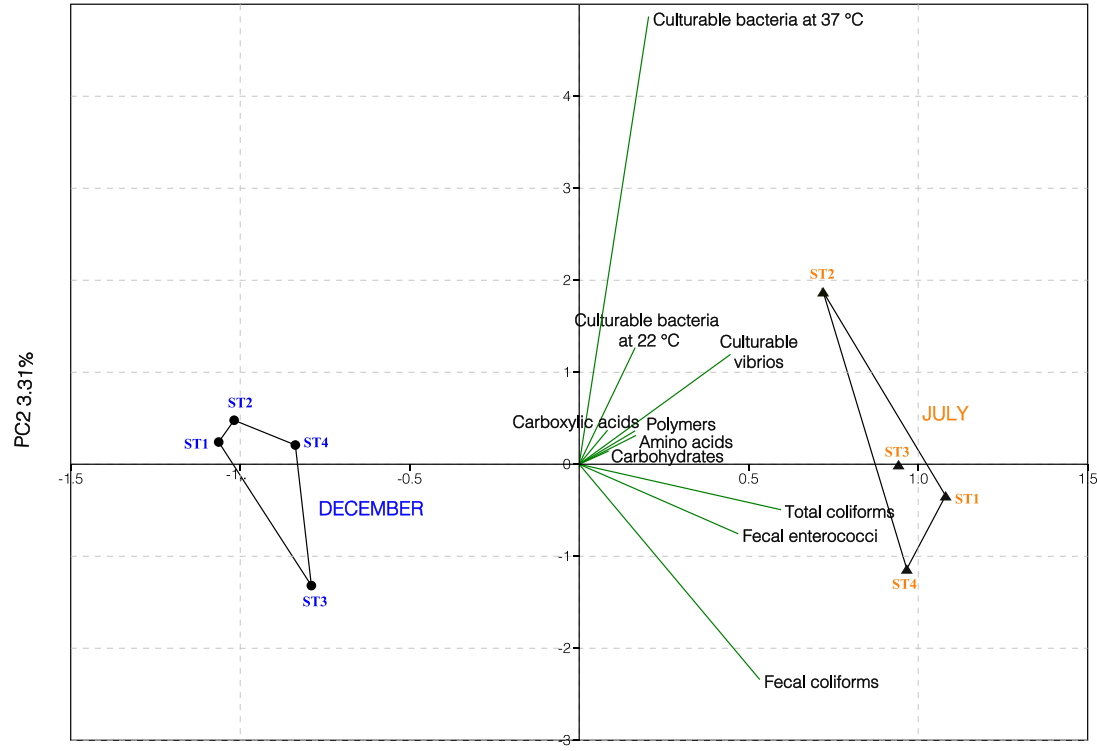

PC1 $92.41 \%$ 
carbohydrates, amino acids, proteins, nucleic acids, lipids, and polymers. Our data showed that most of the amino acids, carbohydrates, carboxylic acids, and several polymers present in the Biolog system were degraded by the microbial community living in the studied area. This result suggests that DOM inputs, coming from sewage wastes, operated as a trophic source, stimulating microbial metabolism and growth.

Moreover, according to the higher bacterial counting recorded in July, the microbial community associated with the seawater in July showed also more versatile substrates utilization patterns compared to the December microbiota. In this regard, we noticed that $\mathrm{L}$-asparagine was the $\mathrm{C}$ source more degraded in July. L-asparagine is a neutral amino acid with polar side chains. L-asparaginase is among the relevant enzymes that can be obtained from marine sources [57]. This amidohydrolase is active on L-asparagine, producing L-aspartate and ammonia, and has also some L-glutaminase activity [58-60]. In this framework, it is noteworthy that several Vibrio species possess L-asparaginase activity [61].

Fluctuations in the abundance of vibrios, with higher concentrations in July compared to December, reflected the trend recorded in the distribution of microbial metabolism, as well as the counting of total marine heterotrophic bacteria, and were consistent with the ecology of these bacteria, whose growth is increased by warm temperature and high nutrient availability [62]. In general, in aquaculture systems, it has been found that, of all the environmental factors, the temperature is the main driving factor of the bacterial community $[63,64]$. Thus, aquaculture outbreaks of aquatic animal diseases are often seasonal, and these outbreaks could be closely related to seasonal changes in microbial populations [65]. Bacteria belonging to the genus Vibrio are of particular concern, as they constitute a considerable part of marine halophilic bacterial populations, are strongly thermo-dependent and are often associated with human and marine animals' diseases, called vibriosis.

Although vibriosis is one of the largest constraints on aquaculture production and one of the major bacterial diseases observed in cultured marine fish worldwide, an epidemic trait of the Vibrio in a Mediterranean mariculture farm is still lacking. Our study is an attempt in this direction. In the examined area we evidenced a core of recurrent vibrios, that do not comprise human pathogens, but some of them represent a serious threat for reared organisms [66-73].

Most of the core recurrent vibrios recorded in our study belong to new species in the genus Vibrio described, in the last decade, associated with marine environments and aquatic eukaryotic organisms. To mention some examples, $V$. litoralis has been firstly isolated from seawater in a Yellow Sea tidal flat in Korea [74]; V. comitans was isolated for the first time from the gut of the abalones Haliotis discus discus, H. gigantea, H. madaka and H. rufescens [75]. Vibrio brasiliensis and $V$. xuii have been detected in the marine aquaculture environment (bivalves, fish, rotifers, and shrimps) [76].
In July, vibrios diversity increased significantly. Among the identified species, the presence of $V$. rotiferianus, $V$. parahaemolyticus, $V$. harveyi and $V$. vulnificus is noteworthy. In particular, $V$. vulnificus is an opportunistic human pathogen, commonly found in warm coastal waters and in the Mediterranean Sea [77]. It can cause severe gastroenteritis from the consumption of raw seafood, as well as wound infections and necrotizing fasciitis, thus posing a health risk to both seafood consumers and fishermen [78]. Infection due to this bacterial species in fish mainly consists of penetration of bacterium to the host tissue, mainly by the chemotactic activity, followed by deployment of the iron sequestering system and eventually damages the fish through extracellular products i.e., haemolysin and protease [11]. Vibrio parahaemolyticus, a seafood borne pathogen coming from the marine environment [79], is responsible for gastroenteritis, sepsis, or wound infection in humans that are infected by eating contaminated raw seafood or wound-related infections [80]. This Vibrio species is an aquatic zoonotic agent and can infect also aquatic animals causing vibriosis in several species of fish, shellfish, and other aquatic animals [81]. In aquaculture reared animals, mainly shrimp, V. parahaemolyticus causes Acute Hepatopancreatic Necrosis Disease (AHPND) or Early Mortality Syndrome (EMS) with economic losses in this sector worldwide [82].

Among the identified species, vibrios of the Vibrio Harveyi clade were present. These are major pathogens of many aquatic organisms, including vertebrates and invertebrates [83]. In particular, $V$. rotiferianus, a marine pathogen causing disease in various aquatic organisms, was originally isolated from cultures of the rotifer Brachionus plicatilis which are important nutrients for fish and crustaceans in aquaculture industries [84]. With the expansion of aquaculture, $V$. harveyi has been identified as a serious source of disease responsible for largescale mass mortality in shrimp farms [85] and is also pathogenic to oysters, fish, seahorses, and lobsters [86]. The presence of $V$. rotiferianus, $V$. parahemolyticus, $V$. harveyi, and $V$. vulnificus in July, in the analyzed seawater samples, led to conclude that in this period of the year marine life is particularly vulnerable to vibrios diseases. This is in agreement with the features of vibrios, which are strongly thermo-dependent and potentially present in a viable but nonculturable (VBNC) state in cold months $[17,87,88]$. Several studies, indeed, have demonstrated that the occurrence of Vibrio bacteria in the NW Mediterranean Sea is climate-linked and can vary greatly under the influence of temperature $[17,87,88]$.

It must be pointed out here that, as it is well known, the examination of intragenus heterogeneity could be limited by the low species-level discriminatory power, particularly among highly genetically related Vibrio species [63, 89]. However, $16 \mathrm{~S}$ rRNA gene metabarcoding sequencing has been and still is used to characterize Vibrio community structure [90,91]. On account of these 
considerations, many efforts are currently underway to improve the taxonomic resolution of Vibrio diversity, and increase the proportion of sequences that can be unambiguously assigned to Vibrio species [92-94].

According to the increase of vibrios diversity, all the other monitored microbiological parameters increased in July. It is well known that the enterococci constitute an indicator for older fecal contamination since they survive better in the environment [95]. Both coliforms and enterococci are frequently used as indicator organisms of fecal contamination of potable and recreational water, as well as food. By contrast, enterococci are not mentioned in the current EU-regulations on the assessment of farming localities for bivalve cultivation. On account of these considerations, we enlarged the spectrum of the microbiological analyses and evaluated both coliforms and fecal enterococci. All the recorded values of microbial pollution indicators were lower than the legal limits of the national and European law, concerning the mussel culture.

Last but not least, of particular interest are the results deriving from the multivariate statistical data analysis by PCA. In this analysis, the pattern arising from the structural and metabolic parameters examined in the two sampling times showed a clear-cut separation between the samples collected in July (characterized mainly by high values of all the examined parameters), and the samples collected in December (characterized mainly by low recorded values). This clear separation allows one-shot microbial multicomponent detection that could be useful to the farmers working in the Mediterranean area to realize a more eco-friendly and sustainable aquaculture approach.

An integrated management perspective should indicate in which period of the year (July and summer) the attention must be pointed to prevent possible disease in the aquaculture farms when the microbial load increases. On account of our results, we strongly suggest improving the microbial surveillance of farming waters in Mediterranean areas in summer. Thus, from this preliminary study, some interesting conclusions can be inferred in the field of environmental concerns. Indeed, the observed responses of the microbial community, in the two sampling times, indicate that the here selected microbial inventory represents a "good indicator" to furnish a clear scenario of the environment, where the mariculture is practiced. Therefore, it could be suggested as an integrative, multiparametric approach for a better surveillance of the microbial quality of farming waters. This is particularly important taking into consideration that, at present, as regards the quality of waters the only regulatory and legal constraints in aquaculture policies are concerning shellfish. Up to now, the EU's water policy is regulated under two instruments: the Water Framework Directive, covering inland and coastal waters; and the Marine Strategy Framework Directive 2008/56/ $\mathrm{EC}$, covering marine waters. This is due mainly to a frequent lack of recognition for aquaculture as an equal user of water resources as compared with other users, such as fisheries or tourism. However, a recent paper by Caruso et al. [21] recommended that the structural or functional prokaryotic variables (biodiversity, abundance, and metabolism) should be included in future implementations of the Marine Strategy Framework. In this scenario, our paper represents a first preliminary attempt toward this direction.

\section{Conclusions}

At present, studies on the microbial communities developing in mariculture areas are still limited. Our paper provides a first insight into the attempt to furnish a set of microbiological parameters, based on culture and molecular methods, useful to assess the water quality in a coastal area of the Mediterranean, where mariculture (Dicentrarcus labrax and Sparus aurata) is practiced. In the rearing, environmental bacterial counting, versatile metabolic pathways for the microbial community, and a broad vibrios diversity were recorded, with higher values especially in July. Within the vibrios community, we identified a core set of Vibrio species, critical to define the health status of the farming environment. Vibrios diversity rose significantly in July and among the identified species the presence of $V$. rotiferianus, $V$. parahemolyticus, $V$. harveyi, and $V$. vulnificus is important for the human and fish disease implications. The analytical approach here suggested could implement the array of the existing strategies for microbial contamination evaluation. Aside from their role for human health risk assessment, the insertion of microbial variables as susceptible indicators of overall ecosystem health status has also been suggested by recent directives on the sustainable management and safeguard of marine and coastal ecosystems. Thus, the here furnished microbial inventory could be suggested as a multiparametric approach for water quality monitoring and the development of more sustainable aquaculture since a clear separation of the measured parameters (structural and functional) was evidenced in the two considered sampling times.

Acknowledgements The authors thanks Dr. Margherita Licciano for her valuable technical support.

Author Contribution Conceptualization: [Loredana Stabili]; methodology: [Loredana Stabili, Marco di Salvo]; formal analysis and investigation: [Adelfia Talà]; writing, review, and editing: [Loredana Stabili, Pietro Alifano, and Adelfia Talà]; funding acquisition: [Loredana Stabili].

Funding Open access funding provided by Università del Salento within the CRUI-CARE Agreement. This work was supported by the Life Project REMEDIA Life "REmediation of Marine Environment and Development of Innovative Aquaculture: exploitaiton of edible/not edible biomasss" (LIFE Environment and Resource Efficiency 2016. LIFE16 $\mathrm{ENV/IT/000343)} \mathrm{funded} \mathrm{by} \mathrm{EU.}$ 
Data availability Not applicable

Code Availability Not applicable

\section{Declarations}

Ethics Approval Not applicable

Consent to Participate Not applicable

Consent for Publication Not applicable

Competing Interests The authors declare no competing interests.

Open Access This article is licensed under a Creative Commons Attribution 4.0 International License, which permits use, sharing, adaptation, distribution and reproduction in any medium or format, as long as you give appropriate credit to the original author(s) and the source, provide a link to the Creative Commons licence, and indicate if changes were made. The images or other third party material in this article are included in the article's Creative Commons licence, unless indicated otherwise in a credit line to the material. If material is not included in the article's Creative Commons licence and your intended use is not permitted by statutory regulation or exceeds the permitted use, you will need to obtain permission directly from the copyright holder. To view a copy of this licence, visit http://creativecommons.org/licenses/by/4.0/.

\section{References}

1. United Nations (2017) World Population Prospects: The 2017 revision, key findings and advance tables. Population Division, United Nations, New York.

2. Karakassis I, Tsapakis M, Hatriyanni E, Papadopoulou KN, Placiti W (2000) Impact of cage farming of fish on the seabed in three Mediterranean coastal areas. ICES J Mar Sci 57:1462-1471

3. Holmer M (2010) Environmental issues of fish farming in offshore waters: perspectives, concerns and research needs. Aquac Environ Interact 1:57-70

4. Danovaro R, Corinaldesi C, La Rosa T, Luna G, Mazzola A, Mirto S, Vezzulli L, Fabiano M (2003) Aquaculture impact on benthic microbes and organic matter cycling in coastal Mediterranean sediments: a synthesis. Chem Ecol 19:59-65

5. Luna GM, Corinaldesi C, Dell'Anno A, Pusceddu A, Danovaro R (2013) Impact of aquaculture on benthic virus-prokaryote interactions in the Mediterranean Sea. Water Res 47:1156-1168

6. Hyland J, Balthis L, Karakassis I, Magni P, Petrov A, Shine J, Vestergaard O, Warwick R (2005) Organic carbon content of sediments as an indicator of stress in the marine benthos. Mar Ecol Prog Ser 295:91-103

7. Aguado-Giménez F, Marín A, Montoya S, Marín-Guirao L, Piedecausa A, Garcia BG (2007) Comparison between some procedures for monitoring offshore cage culture in western Mediterranean Sea. Aquaculture 271:357-370

8. Gifford S, Dunstan RH, O'Connor W, Roberts T, Toia R (2004) Pearl aquaculture profitable environmental remediation? Sci Total Environ 319:27-37

9. Reilly A, Kaferstein F (1997) Food safety hazards and the application of the principles of the hazard analysis and critical control point (HACCP) system for their control in aquaculture production. Aquac Res 28:735-752
10. Bondad-Reantaso MG, Subasinghe R, Arthur JR, Ogawa K, Chinabut S, Adlard RD, Tan Z, Shariff M (2005) Disease and health management in Asian aquaculture. Vet Parasitol 132:249272

11. Chatterjee S, Haldar S (2012) Vibrio related diseases in aquaculture and development of rapid and accurate identification methods. J Mar Sci Res Dev S1:002. https://doi.org/10.4172/2155-9910.S1002

12. Sarjito S, Radjasa OK, Sabdono A, Prayitno SB, Hutabarat S (2009) Phylogenetic diversity of the causative agents of vibriosis associated with groupers fish from Karimunjawa Islands, Indonesia. Curr Res Bacteriol 2:14-21

13. Stabili L, Cardone F, Alifano P, Tredici SM, Piraino S, Corriero G, Gaino E (2012) Epidemic mortality of the sponge Ircinia variabilis (Schmidt,1862) associated to proliferation of a Vibrio bacterium. Microb Ecol 64:802-813

14. Odonkor ST, Ampofo JK (2013) Escherichia coli as an indicator of bacteriological quality of water: an overview. Microbiol Res 4:1

15. Lušić DV, Jozić S, Cenov A, Glada M, Bulić M, Lušić D (2016) Escherichia coli in marine water: Comparison of methods for the assessment of recreational bathing water samples. Mar Pollut Bull 113:438-443

16. Mazzola A, Mirto S, La Rosa T, Fabiano M, Danovaro R (2000) Fish-farming effects on benthic community structure in coastal sediments: analysis of meiofaunal recovery. ICES J Mar Sci 57:14541461

17. Vezzulli L, Chelossi E, Riccardi G, Fabiano M (2002) Bacterial community structure and activity in fish farm sediments of the Ligurian Sea (Western Mediterranean). Aquac Int 10:123-141

18. Bedwell MS, Goulder R (1996) Bacterial outputs from ponds and tanks used in intensive fish farming. Lett Appl Microbiol 23:412416

19. La Rosa T, Mirto S, Marino A, Alonzo V, Maugeri TL, Mazzola A (2001) Heterotrophic bacteria community and pollution indicators of mussel-farm impact in the Gulf of Gaeta (Tyrrhenian Sea). Mar Environ Res 52:301-321

20. Caruso G, Caruso R, Sarà G (2020) Microbiological controls in polyculture farming: a pilot case study in the Castellammare Gulf (Sicily). J Clin Microbiol Biochem Technol 6:014-028

21. Caruso G, La Ferla R, Azzaro M et al (2016) Microbial assemblages for environmental quality assessment: knowledge, gaps and usefulness in the European Marine Strategy Framework Directive. Crit Rev Microbiol 42:883-904

22. Wang S, Yan Z, Wang P, Zheng X, Fan J (2020) Comparative metagenomics reveals the microbial diversity and metabolic potentials in the sediments and surrounding seawaters of Qinhuangdao mariculture area. PLoS One 15(6):e0234128

23. Kearns PJ, Angell JH, Feinman SG, Bowen JL (2015) Long-term nutrient addition differentially alters community composition and diversity of genes that control nitrous oxide flux from salt marsh sediments. Estuar Coast Shelf Sci 154:39-47

24. Chariton AA, Sun Y, Gibson JF, Webb JA, Leung KMY, Hickey CW, Hose GC (2016) Emergent technologies and analytical approaches for understanding the effects of multiple stressors in aquatic environments. Mar Freshw Res 67:414-428

25. Gryta A, Rac M, Oszust K (2014) The application of the Biolog EcoPlate approach in ecotoxicological evaluation of dairy sewage sludge. Appl Biochem Biotechnol 174:1434-1443

26. Caroppo C, Stabili L, Aresta M, Corinaldesi C, Danovaro R (2006) Impact of heavy metals and PCBs on marine picoplankton. Environ Toxicol 21(6):541-551. https://doi.org/10.1002/tox.20215

27. Atlas RM, Bartha R (1998) Microbial ecology: fundamentals and applicationsFourth edn. Benjamin cummings, California, p 694

28. Van Nevel S, Koetzsch S, Proctor CR, Besmer MD, Prest EI, Vrouwenvelder JS, Knezev A, Boon N, Hammes F (2017) Flow cytometry bacterial cell count challenge conventional heterotrophic 
plate counts for routine microbiological drinking water. Water Res 113:191-206

29. Wang R, He J, Wang J (2016) Heterotrophic bacterial abundance and diversity in the farming environment and guts of the oyster Crassostrea hongkongensis. J Shellfish Res 35(2):343-350

30. Arias-Moscoso JL, Espinoza-Barrón LG, Miranda-Baeza A, RivasVega ME, Nieves-Soto M (2018) Effect of commercial probiotics addition in a biofloc shrimp farm during the nursery phase in zero water exchange. Aquac Rep 11:47-52

31. ISO 6222:2010 (2010) Water quality - enumeration of culturable microorganisms - colony count by inoculation in a nutrient agar culture medium. International Organization for Standardization, Geneva

32. Stabili L, Gravili C, Tredici SM, Piraino S, Talà A, Boero F, Alifano P (2008) Epibiotic Vibrio luminous bacteria isolated from some hydrozoa and bryozoa species. Microb Ecol 56:625-636

33. APHA (2005) Standard methods for the examination of water and wastewater21st edn. American Public Health Association/ American Water Works Association/Water Environment Federation, Washington DC

34. ISO 9308-3 (1998) Water quality-detection and enumeration of Escherichia coli and coliform bacteria - part 3: miniaturized method (most probable number) for the detection and enumeration of E. coli in surface and wastewater

35. ISO 7899-1:1998 (1998) Water quality-detection and enumeration of intestinal enterococci in surface and wastewater-part 1: miniaturized method (most probable number) by inoculation in liquid medium. International Organization for Standardization, Geneva

36. Stabili L, Licciano M, Giangrande A, Fanelli G, Cavallo RA (2006) Sabella spallanzanii filter-feeding on bacterial community: ecological implications and applications. Mar Environ Res 61:74-92

37. Planas M, Pérez-Lorenzo M, Hjelm M, Gram L, Fiksdal IU, Bergh Ø, Pintado J (2006) Probiotic effect in vivo of Roseobacter strain 27-4 against Vibrio (Listonella) anguillarum infections in turbot (Scophthalmus maximus L.) larvae. Aquaculture 255:323-333

38. Sambrook J, Russell DW (2001) Molecular cloning: a laboratory manual3rd edn. Cold Spring Harbor Laboratory Press

39. Romano S, Di Salvo M, Rispoli G, Alifano P, Perrone MR, Talà A (2019) Airborne bacteria in the Central Mediterranean: structure and role of meteorology and air mass transport. Sci Total Environ 697(134020): 134020

40. Wang Q, Garrity GM, Tiedje JM, Cole JR (2007) Naive Bayesian classifier for rapid assignment of rRNA sequences into the new bacterial taxonomy. Appl Environ Microbiol 73:5261-5267

41. Roura A, Doyle SR, Nande M, Strugnell JM (2017) You are what you eat: a genomic analysis of the gut microbiome of captive and wild Octopus vulgaris paralarvae and their zooplankton prey. Front Physiol 31(8):362

42. Werner JJ, Koren O, Hugenholtz P, DeSantis TZ, Walters WA, Caporaso JG, Angenent LT, Knight R, Ley RE (2012) Impact of training sets on classification of high-throughput bacterial $16 \mathrm{~S}$ rRNA gene surveys. ISME. 6:94-103

43. Rizzo L, Pusceddu A, Stabili L, Alifano P, Fraschetti S (2017) Potential effects of an invasive seaweed (Caulerpa cylindracea, Sonder) on sedimentary organic matter and microbial metabolic activities. Sci Rep 7(1):12113. https://doi.org/10.1038/s41598017-12556-4

44. Stabili L, Rizzo L, Pizzolante G, Alifano P, Fraschetti S (2017) Spatial distribution of the culturable bacterial community associated with the invasive alga Caulerpa cylindracea in the Mediterranean Sea. Mar Environ Res 125:90-98

45. Basso L, Rizzo L, Marzano M, Intranuovo M, Fosso B, Pesole G, Piraino S, Stabili L (2019) Jellyfish summer outbreaks as bacterial vectors and potential hazards for marine animals and humans health? The case of Rhizostoma pulmo (Scyphozoa, Cnidaria). Sci Total Environ 692:305-318

46. Truu M, Juhanson J, Truu J (2009) Microbial biomass, activity and community composition in constructed wetlands. Sci Total Environ 407:3958-3971

47. Garland JL, Mills AL (1991) Classification and characterization of heterotrophic microbial communities on basis of patterns community-level sole-carbon-source utilization. Appl Environ Microbiol 57:2351-2359

48. Garland JL (1997) Analysis and interpretation of community-level physiological profiles in microbial ecology. FEMS Microbiol Ecol 24:289e300. https://doi.org/10.1111/j.15746941.1997.tb00446.x

49. Hammer Ø, Harper D, Ryan P (2001) PAST: paleontological statistics software package for education and data analysis. Palaeontol Electron 4:1-9

50. Munday BW, Eleftheriou A, Kentouri M, Divanach P (1994) Quantitative statistical analysis of the literature concerning the interaction of the environment and aquaculture - identification of gap and lacks. J Appl Ichthyol 10:319-325

51. Bourne DG, Young N, Webster N, Payne M, Salmon M, Demel S, Hall M (2004) Microbial community dynamics in a larval aquaculture system of the tropical rock lobster, Panulirus ornatus. Aquaculture 242:31-51

52. Powell SM, Chapman CC, Bermudes M, Tamplin ML (2013) Dynamics of seawater bacterial communities in a shellfish hatchery. Microb Ecol 66:245-256

53. Hovanec TA, DeLong EF (1996) Comparative analysis of nitrifying bacteria associated with freshwater and marine aquaria. Appl Environ Microbiol 62:2888-2896

54. Yan FJ, Tian XL, Dong SL, Yang G (2014) Seasonal variation of functional diversity of aquatic microbial community in Apostichopus japonicus cultural pond. Chin J Appl Ecol 25: 1499-1505

55. Caruso G, Genovese L, Mancuso M, Modica A (2003) Effects of fish farming on microbial enzyme activities and densities: comparison between three Mediterranean sites. Lett Appl Microbiol 37: 324-328

56. Yoza BA, Harada RM, Nihous GC, Li QX, Masutani SM (2007) Impact of mariculture on microbial diversity in sediments near open ocean farming of Polydactylus sexfilisi. Ecol Indic 7:108-122

57. Izadpanah Qeshmi F, Homaei A, Fernandes P, Javadpour S (2018) Marine microbial L-asparaginase: biochemistry, molecular approaches and applications in tumor therapy and in food industry. Microbiol Res 208:99-112. https://doi.org/10.1016/j.micres.2018. 01.011

58. El-Bessoumy AA, Sarhan M, Mansour J (2004) Production, isolation, and purification of L-asparaginase from Pseudomonas aeruginosa 50071 using solid-state fermentation. J Biochem Mol Biol 37:387-393

59. El-Sharkawy AS, Farag AM, Embaby AM, Saeed H, El-Shenawy M (2016) Cloning, expression and characterization of aeruginosa EGYII L-asparaginase from Pseudomonas aeruginosa strain EGYII DSM 101801 in E. coli BL21 (DE3) pLysS. J Mol Catal B Enzym 132:16-23

60. Labrou NE, Muharram MM (2016) Biochemical characterization and immobilization of Erwinia carotovora L-asparaginase in a microplate for high-throughput biosensing of L-asparagine. Enzym Microb Technol 92:86-93

61. Dey SK, Raha SK, Roy SK, Chakrabarty SL (1988) Comparison of L-asparaginase activity in different species of Vibrio. Indian J Med Res 88:398-403

62. Colwell RR (1984) Vibrios in the environment. Wiley, New York, pp 1-634

63. Pascual J, Carmen Macian M, Arahal DR, Garay E, Pujalte MJ (2010) Multilocus sequence analysis of the central clade of the 
genus Vibrio by using the $16 \mathrm{~S}$ rRNA, recA, pyrH, rpoD, gyrB, retB and toxR genes. Int J Syst Evol Microbiol 60:154-165

64. Tang YY, Tao PY, Tan JG, Mu HZ, Peng L, Yang DD, Tong SL, Chen LM (2014) Identification of bacterial community composition in freshwater aquaculture system farming of Litopenaeus vannamei reveals distinct temperature-driven patterns. IJM 15:13663-13680

65. Zhang H, Sun Z, Liu B, Xuan Y, Jiang M, Pan Y, Zhang Y, Gong Y, Lu X, Yu D, Kumar D, Hu X, Cao G, Xue R, Gong C (2016) Dynamic changes of microbial communities in Litopenaeus vannamei cultures and the effects of environmental factors. Aquaculture 455:97-108

66. Wang X, Zhang Y, Qin G, Luo W, Lin Q (2016) A novel pathogenic bacteria (Vibrio fortis) causing enteritis in cultured seahorses, Hippocampus erectus Perry, 1810. J Fish Dis 39:765-769

67. Romalde JL, Diéguez AL, Lasa A, Balboa S (2014) New Vibrio species associated to molluscan microbiota: a review. Front Microbiol 4:1-10

68. Garnier M, Labreuche Y, Nicolas JL (2008) Molecular and phenotypic characterization of Vibrio aestuarianus subsp. francensis subsp. nov., a pathogen of the oyster Crassostrea gigas. Syst Appl Microbiol 31:358-365

69. Austin B, Austin D, Sutherland R, Thompson F, Swings J (2005) Pathogenicity of vibrios to rainbow trout (Oncorhynchus mykiss, Walbaum) and Artemia nauplii. Environ Microbiol 7:1488-1495

70. Ben-Haim Y, Rosenberg E (2002) A novel Vibrio Sp. pathogen of the coral Pocillopora damicornis. Mar Biol 141:47-55

71. Verdonck L, Grisez L, Sweetman E, Minkoff G, Sorgeloos P, Ollevier F, Swings J (1997) Vibrios associated with routine productions of Brachionus plicatilis. Aquaculture 149:203-214

72. Austin B, Austin DA (eds) (1999) Bacterial fish pathogens. Disease of farmed and wild fish. Springer/Praxis Publishing, Chichester, $p$ 552

73. Sugumar G, Nakai T, Hirata Y, Matsubara D, Muroga K (1998) Vibrio splendidus biovar II as the causative agent of bacillary necrosis of Japanese oyster Crassostrea gigas larvae. Dis Aquat Org 33:111-118

74. Nam Y-D, Chang H-W, Park JR, Kwon H-J, Quan X-Z, Park Y-H, Kim B-C, Bae JW (2007) Vibrio litoralis sp. nov., isolated from a Yellow Sea tidal flat in Korea. Int J Syst Evol Microbiol 57:562565

75. Sawabe T, Fujimura Y, Niwa K, Aono H (2007) Vibrio comitans sp. nov., Vibrio rarus sp. nov. and Vibrio inusitatus sp. nov., from the gut of the abalones Haliotis discus discus, H. gigantea, H. madaka and H. rufescens. Int J Syst Evol Microbiol 57:916-922

76. Thompson FL, Li Y, Gomez-Gil B, Thompson CC, Hoste B, Vandemeulebroecke K, Rupp GS, Pereira A, De Bem MM, Sorgeloos P, Swings J (2003) Vibrio neptunius sp. nov., Vibrio brasiliensis sp. nov. and Vibrio xuii sp. nov., isolated from the marine aquaculture environment (bivalves, fish, rotifers and shrimps). Int J Syst Evol Microbiol 53:245-252

77. Maugeri TL, Carbone M, Fera MT, Gugliandolo C (2006) Detection and differentiation of Vibrio vulnificus in seawater and plankton of a coastal zone of the Mediterranean Sea. Res Microbiol 157:194-200

78. Jones MK, Oliver JD (2009) Vibrio vulnificus: disease and pathogenesis. Infect Immun 77:1723-1733

79. Kanjanasopa D, Pimpa B, Chowpongpang S (2011) Occurrence of Vibrio parahaemolyticus in cockle (Anadaragranosa) harvested from the south coast of Thailand. Songklanakarin J Sci Technol 33:295-300
80. Zhang Q, Dong X, Chen B, Zhang Y, Li W, Zu Y (2016) Zebrafish as a useful model for zoonotic Vibrio parahaemolyticus pathogenicity in fish and human. Dev Comp Immunol 55:59-16

81. Anjay Das SC, Kumar A, Kaushik P, Kurmi B (2014) Occurrence of Vibrio parahaemolyiticus in marine fish and sellfish. Indian J Geo Mar Sci 43:887-890

82. Pui CF, Bilung LM, Zin NBM, Abidin NNBZ, Vincent M, Apun K (2014) Risk of acquiring Vibrio parahaemolyticus in water and shrimp from an aquaculture farm. Kuroshio Sci 8:59-62

83. Urbanczyk H, Ogura Y, Hayashi T (2013) Taxonomic revision of Harveyi clade bacteria (family Vibrionaceae) based on analysis of whole genome sequences. Int J Syst Evol Microbiol 63:2742-2751

84. Gomez-Gil B, Thompson FL, Thompson CC, Swings J (2003) Vibrio rotiferianus sp. nov., isolated from cultures of the rotifer Brachionus plicatilis. Int J Syst Evol Microbiol 53:239-243

85. Owens L, Busico-Salcedo N (2006) Vibrio harveyi: pretty problems in paradise. In: Thompson FL (ed) The biology of vibrios. ASM Press, Washington, D.C., pp 266-280

86. Vidgen M, Carson J, Higgins M, Owens L (2006) Changes to the phenotypic profile of Vibrio harveyi when infected with the Vibrio harveyi myovirus-like (VHML) bacteriophage. J Appl Microbiol 100:481-487

87. Vezzulli L, Colwell RR, Pruzzo C (2013) Ocean warming and spread of pathogenic Vibrios in the aquatic environment. Microb Ecol 65:817-825

88. Vezzulli L, Pezzati E, Brettar I, Höfle M, Pruzzo C (2015) Effects of global warming on Vibrio ecology. Microbiol Spectr 3(3):VE0004-VE-2014. https://doi.org/10.1128/microbiolspec.VE-00042014

89. Thompson CC, Carolina A, Vicente P, Souza RC, Vasconcelos ATR, Vesth T, Alves N, Ussery DU, Iida T, Thompson FL (2009) Genomic taxonomy of vibrios. BMC Evol Biol 9:258. https://doi.org/10.1186/1471-2148-9-258

90. Green TJ, Siboni N, King WL, Labbate M, Seymour JR, Raftos D (2019) Simulated marine heat wave alters abundance and structure of vibrio populations associated with the pacific oyster resulting in a mass mortality event. Microb Ecol 77:736-747

91. Xu W, Gong L, Yang S, Gao Y, Ma X, Xu L, Chen H, Luo Z (2020) Spatiotemporal dynamics of Vibrio communities and abundance in Dongshan Bay, South of China. Front Microbiol 11: 575287. https://doi.org/10.3389/fmicb.2020.575287

92. Jesser KJ, Noble RT (2018) Characterizing the ecology of Vibrio in the Neuse River Estuary, North Carolina using heat shock protein 60 (hsp60) next-generation amplicon sequencing. Appl Environ Microbiol 84:e00333-e00318. https://doi.org/10.1128/AEM. 00333-18

93. King WL, Siboni N, Kahlke T, Green TJ, Labbate M, Seymour JR (2019) A new high throughput sequencing assay for characterizing the diversity of natural Vibrio communities and its application to a pacific oyster mortality event. Front Microbiol 10:2907. https://doi. org/10.3389/fmicb.2019.02907

94. Liang J, Liu J, Wang X, Lin H, Liu J, Zhou S, Sun H, Zhang XH (2019) Spatiotemporal dynamics of free-living and particleassociated Vibrio communities in the northern Chinese marginal seas. Appl Environ Microbiol 85:e217-e219. https://doi.org/10. 1128/AEM.00217-19

95. Noble RT, Lee IM, Schiff KC (2004) Inactivation of indicator microorganisms from various sources of faecal contamination in seawater and freshwater. J Appl Microbiol 96(3):464e472-464e472. https://doi.org/10.1111/j.1365-2672.2004.02155.x 